MedieKultur | Journal of media and communication research | ISSN 1901-9726

Article - Open section

\title{
Critical reflections on the theory versus practice debate in communication for development
}

\section{Linje Manyozo}

MedieKultur 2016, 116-134

Published by SMID | Society of Media researchers In Denmark | www.smid.dk The online version of this text can be found open access at www.mediekultur.dk

\begin{abstract}
Even though the cliche 'theory is practice' registers in most communication for development debates, available evidence seems to suggest there is a growing chasm between the theory and practice of communication for development. This discussion argues that, with the increasing demand by governments and organisations for communication for development specialists, universities and training providers should rethink their graduate curricula. As course content, teaching methodologies and theoretical paradigms are revisited, trainers need to grill students on how the contestation of power is central to the application of communication in development. This paper advances two arguments. The first is that communication for development training has to begin listening to the innovative thinking that is shaping practice on the ground if the curriculum is to stay relevant. The second is that such programmes have forge strong linkages with development studies departments to ensure that students are well-grounded in development theory and practice.
\end{abstract}

\section{Key Words}

Communication for development, social change, development, training, specialist 
Article: Critical reflections on the theory versus practice debate in communication ...

\section{Introduction}

The paper explores the apparent growing disjuncture between communication for development theory as offered in graduate programmes and the demands of the practice on the ground. For a long time since the 1970s, only the University of the Philippines at Los Baños offered programmes in communication for development (C4D) -- first, as a major within the Agriculture Communication Masters and, second, as fully-fledged degree programmes under the College of Development Communication. Beginning in the 1990s, other C4D degree programmes would spring up -- first, in the Southeast Asian Region, Africa and, then, in Latin America, which also has a deeper and richer experience with C4D (Ramiro Beltran, 1993/2004). In the mid-2000s, numerous programmes would emerge in European and North American Universities -- in particular, at Ohio, Guelph, Malmo, East Anglia, the London School of Economics and Political Science, City University, Westminster and others. The establishment of the Communication for Social Change Consortium in New York and its ability to forge a network of C4D training institutions provided a space for reflexive approaches towards teaching and learning in the field.

This paper is a two-tiered conversation. First, it is a continuation of a conversation with practitioner-thinkers Alfonso Gumucio Dagron and Clemencia Rodriguez (2006), who distinguish between general training in media and communication and specialist training in communication for development. The second conversation is a personal experience. After teaching C4D at the London School of Economics and Political Science (LSE) for slightly over 4 years, I returned to development practice as a C4D Specialist -- first, with the Global Fund and World Bank-supported National AIDS Commission in Malawi and, later on, with UNICEF. I must confess that I was slightly unprepared for the complexities that are currently shaping C4D practice on the ground. Building on these conversations and experiences, the paper draws on what Silvio Waisbord (2005) defines as the gap between theory and practice in order to examine the challenges and opportunities that are shaping the C4D theory-practice debate.

\section{The Context of the Debate}

When I re-joined development practice in 2012, my job description included tasks such as designing and implementing social mobilisation interventions, managing stakeholder relationships, and monitoring and evaluating other basic things about C4D. The eye opener was the conversation I had with an England-based consultant, Bruce MacKay, who had been hired by DFID to carry out background research on investment thinking or business case in HIV prevention. Professional interactions with MacKay would shake my professional comfort zones. My conversations with him revolved around economic appraisals, financial and commercial management and cost-benefit analyses, especially in relation to how many lives an intervention could save with a specific amount of financial resources. Since I started working in C4D in the 2000s, I was being challenged to think like a business 
person - to think specifically about the invested resources and intended outcomes. So what is 'investment thinking'?

Investment thinking is also sometimes known as the business case. In practice, investment case consideration allows policymakers and development planners to define effective interventions in terms of their unit costs and expected benefits -- for example, in terms of deaths or infections averted (UK Government, 2013; UNAIDS, 2012). Many factors contribute to the integration of investment thinking into public health policy planning and implementation. Principal among these factors are the dwindling available resources and, hence, the need for smart and cost effective programming approaches (UNAIDS, 2012). Applying the business case or investment approach provides an opportunity for the maximization of the benefits of interventions. It also supports the rational resource allocation based on the country's evidence base and context by prioritising the most cost-effective programme activities (UK Government, 2013). For HIV prevention, biomedical interventions are easier to cost compared to non-biomedical interventions. For example, the unit cost of HIV testing and counselling is US\$10 per person, anti-retroviral treatment is US\$515 per person per annum, while VMMC costs are US\$65 per person. From these unit costs, scientists are able to use goals or spectrum models (UNAIDS, 2012) to forecast how many lives could be saved, how many deaths averted, and so forth. The realisation in these conversations with MacKay was that my accumulative C4D training over the years had fallen short, and I needed to reboot my thinking and practice. Yet, it has to be acknowledged that 'investment thinking' is also problematic: it seems to commodify social change, as if it were a product that could be pre-planned, pre-determined and delivered in quantifiable units and within a given period of time.

\section{Communication for Development}

Also known as development communication, development support communication or, more recently, as communication for social change, communication for development was first articulated as a field of study and a professional practice by Nora Quebral $(1988,2011)$ in the 1970s. At that time, the College of Agriculture was already offering 'development communication' as a major within its Masters in Agriculture Communication Programme. Only with the 1974/75 school calendar did the University of the Philippines at Los Baños (UPLB) begin offering bachelor's degrees in the field, making it the first training institution in the world to do so. Later on, the College of Development Communication was established, and a series of graduate programmes were introduced. In those new degree programmes, there were four areas of focus - development broadcasting, educational communication, development journalism and science communication. These provided students with a holistic understanding of development challenges in the Global South and, from that understanding, enabled them to develop effective communication interventions to address the development challenges (Quebral, 1988, 2011). 
What this shows is that development and communication were considered two separate but interdependent theoretical entities (Quebral, 1988, 2011). Thus, to be a development communication specialist, one had to understand development holistically; and, using that knowledge, one would initiate communication programming that would empower people to find solutions to their development challenges. As such, studying and understanding development was a must (Quebral, 1988). In an email conversation advising me on a proposal for a C4D master's programme that I had put together at the University of Fort Hare, Quebral (in Manyozo, 2012, p. 9) elucidated C4D training as:

\begin{abstract}
A systematic education with objectives, methodologies and outcomes but which happens outside the formal school system. It does not promote only one course of action for everyone but instead offers an array of choices from which the users of communication select what is right for them, given their needs and circumstances. [C4D] must help equip the users, however, with the capability to choose and the information and knowledge base from which to choose. [...] For people to dialogue, they must have both a knowledge base and the capability to choose. That is why our undergraduate curriculum has a technical course component, which introduces students to the discipline of learning subject matter that they can communicate.
\end{abstract}

Over the years, terms and definitions have flourished. Quebral (2011) herself acknowledges the changes and revisions that have characterised her own definition with an emphasis on collaboration and planned transformation. Informed by Freire's critical pedagogy, Quebral's insights, and personal encounters with development practice, I have defined C4D as the deliberate, politically-conscious and livelihood-driven employment of media and communications to transform the political economy of development in ways that enable oppressed groups to determine the direction and benefit of interventions (Manyozo, 2012). The point is that, no matter how participatory or communicative a development process might be, nothing will change if the structures and institutions of inequality remain in place.

Yet, a critical juncture that has shaped C4D graduate training has emerged from three developments. The first has been the publication of four major books in the field. These are: Media and Glocal Change: Rethinking Communication for Development (Hemer \& Tufte, 2005), Communication for Social Change Anthology: Historical and Contemporary Readings (Gumucio Dagron \& Tufte, 2006), The Handbook of Global Health Communication, Development and Social Change (Obregon \& Waisbord, 2012), and The Handbook of Development Communication and Social Change (Gwin Wilkins, Tufte \& Obregon, 2014). These publications have enabled the authors to take C4D from the margins of scholarly exploration to mainstream media and communication scholarship. Significantly, these publications could be considered a major turn in communication for development training as they have provided a guiding framework for curriculum development.

The second development was Waisbord's contribution to the Glocal Change Reader (Hemer \& Tufte, 2005). Waisbord (2005, p. 78) provides a scaffold comprising five attributes that characterise the field by observing: 
Article: Critical reflections on the theory versus practice debate in communication ...

There is growing consensus around five ideas in thinking and practicing development communication: the centrality of power, the integration of top down and bottom-up approaches, the need to use a communication 'tool-kit' approach, the articulation of interpersonal and mass communication, and the incorporation of personal and contextual factors.

What Waisbord spells out here impacts the way universities should think about C4D training. He recognizes the centrality of power, contending that planning and implementing development requires that trainers seriously consider the stakeholder relationships that underpin policy formulation and implementation (Waisbord, 2005). The role of media and communications in this case is to offer a platform where marginalised people can contest both political and economic power in order to enable them to transform specific development systems to their benefit. For Waisbord therefore, power becomes a significant concept and the theory around which communication for development training should be built. In the LSE's Media and Communication Department (which I consider to be one of the finest), there is a compulsory course ('Theories and Concepts in Media and Communication') for the master's students in Media, Communication and Development, helping them understand the mediation of power (Livingstone, 2009).

The third factor was very a small event that had massive ramifications for C4D training. This was the first Communications and Social Change Conference held in Bellagio, Italy in April 1997. A second one was held in 2004. Supported by the Rockefeller Foundation, it brought together a small group of 22 professionals "to explore the vast possibilities of new communications for social change" (Rockefeller Foundation, 1997, p. 5). This conference would contribute to the shaping of the communication for social change model that is discussed later, but it also, significantly, laid the groundwork for the first and only World Congress on Communication for Development, which the Food and Agriculture Organisation (FAO) would organise and host in Rome in 2006. The Bellagio Conferences and, then, the World Congress worked to ensure the institutionalisation of C4D within international development organisations.

\section{Communication for Development Training: Two Perspectives}

Two dominant perspectives on conceptualizing and defining communication for development training were propounded (Manyozo, 2007). These were the development communication and the communication for social change perspectives. It is important that scholars and students of society pay critical attention to the philosophical frameworks within which these notions evolved.

\section{The Development Communication Model}

The development communication model emphasises the location of communication for development training within various development studies and paradigms. Quebral (1988, p. 8) argues that C4D "is coloured" more by how we define development, which is "the 
stronger principle in the tandem" to the extent that any change in the definition of development automatically changes the meaning of C4D. As many C4D training programmes demonstrate, the development theory perspective offers parallel comparisons between changing Western development theories. And this means seeing the field through the Western lenses. C4D, therefore, is presented as a response to both development theories and the criticisms that such development theories receive (Gumucio Dagron \& Tufte, 2006; Hemer \& Tufte, 2005; Gwin Wilkins, Tufte \& Obregon, 2014; Obregon \& Waisbord, 2012).

Informed by and married to Western development thinking, this training model has its roots in agricultural extension programmes of the University of the Philippines at Los Baños (UPLB) and other Southeast Asian universities, Bretton Woods institutions (especially, the World Bank) and North American universities (especially, Cornell, Wisconsin, Guelph and other land grant institutions). The early training experiments would produce graduates whose expertise lay in creatively developing and disseminating agricultural knowledge to rural farmers; hence, the initial emphasis was on knowledge management and dissemination. As a training model, development communication recognises the challenges of underdevelopment as a result of colonialism and imperialism. Historically, this model evolved from within universities; but, over time, it was complemented by international development organisations, which saw the need for interactive communication processes that would encourage community participation and ownership of development interventions (Gumucio Dagron \& Rodriguez, 2006; Quebral, 2011; Ramiro Beltran, 1993/2004; Waisbord, 2005). An excellent example is UNDP's Bangkok Office, which would establish the Development Support Communication Unit in the 1970 s.

Probably under the influence of the UPLB, other universities have employed a similar C4D training model in designing their own graduate programmes. These universities include: Kasetsart University in Thailand, Govind Ballabh Pant University of Agriculture and Technology in India, the University of Malawi at Chancellor College, and the Universities of Reading and East Anglia in the UK. Nevertheless, as demonstrated in Media, Development and Communication (2012), development is an equally a contested space. Defining development goes beyond being critical of its dominant theorists and approaches. It implies that we are able to understand and appreciate alternative theories and positions that underpin its exposition. The first question to ask any student of or expert in communication for development is of which development are they an expert? Many people living on the periphery of modernity emphasise they want development they can touch, development they can feel in their hearts, development whose form they can describe, development with a face, a body (Manyozo, 2012). This is the development of those left behind, the subaltern. Such development is often concerned with livelihood issues, such as housing, food, employment, agriculture, public health, disease prevention, climate change and other development-related issues, especially those revolving around the MDGs or the SDGs. And the relevant C4D training aims to provide the intellectual space to allow experts 
Article: Critical reflections on the theory versus practice debate in communication ...

and communities to think of creative and effective ways of bringing communities into the decision-making process that determines interventions and the resources to be employed.

\section{The Social Change Model}

The social change model is largely associated with the Latin American school of communication for social change with roots in postcolonial critiques of development theory, liberation theology, the experimental works of community radio and other community-based institutions of civil society (Ramiro Beltran, 1993/2004). But, in modern times, it is associated with the work of the Rockefeller Foundation -- especially, the 1997 and 2004 Bellagio Conferences (Rockefeller Foundation, 1997). Communication for social change (CFSC) as an alternative concept to C4D emerged from these meetings. But, as mentioned before, the groundwork for this concept was laid years earlier in the works of Gustavo Gutierrez, Paulo Freire, Camiro Torres, Oscar Ramires, Juan Diaz Bordenave, the Catholic Church and numerous community development experiments (Ramiro Beltran, 1993/2004; Gumucio Dagron \& Tufte, 2006; Hemer \& Tufte, 2005).

Major advocates of this model have been the Communication for Social Change Consortium and the Journalism and Communication Program at the University of Queensland, where Jan Servaes would establish the Centre of Communication for Social Change (CFSC) in the 2000s. Servaes himself has maintained the name, Communication for Development and Social Change -- perhaps, an attempt to bring the two models together. The CfSC Consortium has been publishing Mazi, a CfSC report (a resurrection of sorts of the defunct Development Communication Report), and has facilitated the creation of the network of universities offering courses and programmes in communication for social change. This network, REDECAMBIO (www.redcambio.org), is now based at the Corporacion Universitaria Minuto de Dios UNIMINUTO in Bogota, Colombia.

The social change model largely involves training institutions, practitioners and scholars examining histories of how communication experiments have contributed to social change over a period of time (Rockefeller Foundation, 1997). In part, such perspectives have their origins in social theory but, as observed in passing, have also erected their theoretical springboard in the liberation theology and critical pedagogy of Gustavo Gutierrez and Paulo Freire, the Latin American dependency/structuralist perspectives, concepts of public sphere and deliberative democracy, and, more recently, Clemencia Rodriguez's citizens' media. Other theoretical contributions have come from entertainment-education as developed by Miguel Sabido and the Population Communication International and elaborated by the Johns Hopkins University.

This model, therefore, has usually been built on bodies of work in critical theories, democracy and good governance, media effects research, or even cultural theories. The interest is in showing how strategically-designed communication systems and programmes provide public and democratic spheres in which people generate critical and deliberative dialogues leading to the strengthening of civil society, empowerment and social action. 
Sonia Livingstone (2009, p. 1) tells it like it is: It is about exploring "the mediation of everything". Building on such theoretical terrains, the social change model can, thus, be seen as an attempt to formulate a training paradigm that is relevant to both developing and developed societies. Since the term 'development' is seen as reducing issues of empowerment to livelihoods only, the term 'communication for social change' has been promoted, in particular, by a group of researchers and practitioners from Latin America since it is seen to embrace issues of empowerment, active citizenship and social change.

This CfSC model, therefore, should be understood within the context of the intrusive and, often, political and military involvement of the US government in Latin America, which resulted in undermining successive leftist governments and seeming support for military and political dictatorships. Conceiving deliberative development under such conditions was, and is, unconceivable -- hence, the emphasis on the social change model, which underscored the need for total transformation of society. Examples of graduate programmes promoting the social change model might include the Catholic University of Peru's MA in Communication for Social Change Programme and a host of similar programmes in the region from Mexico to Chile, which may not be specifically known as communication for social change but are geared towards achieving the same objectives (Ramiro Beltran, 1993/2004). The adoption of the model has, thus, revitalized communication and journalism departments to strengthen their offerings to deal with emerging and challenging social issues, such as war, conflict, human rights, and governance as well as corruption (Ramiro Beltran, 1993/2004). It must be acknowledged that some development communication model approaches in social mobilisation and advocacy focus on engagement strategies relying on face-to-face interactions and have become irrelevant in urban economies (Gumucio Dagron \& Tufte, 2006; Hemer \& Tufte, 2005).

Nevertheless, the concept of social change is as slippery as it is problematic. Social change can be conceptualised as properly planned processes of structural and cultural transformation of systems and institutions as a result of a critical analysis of the causes of underlying problems. In traditional and colonial anthropology, social change was associated with modernity, the rapid adoption of technology and the abandonment of traditional practices that were considered an impediment to development. The Rockefeller Foundation introduces and discusses an integrated model of communication for social change as "an interactive process where community dialogue and collective action work together to produce social change in a community" to improve the health and welfare of communities (Figueroa, Kincaid, Rani \& Lewis, 2002, p. 5). Postcolonial thinking, globalisation, cultural studies and better understanding of concepts of community participation have enriched our understanding of social change not just as total transformation of institutions and societies. Rather it is about people's empowerment, building of social capital, harnessing of local knowledge and increasing civil participation local governance. 


\section{Some Key Graduate Training Programmes}

A brief survey of established graduate programmes in the field suggests that most of them are located in communication, journalism or media and communication schools and departments, which is not a problem in itself; but suffice to mention that, if, as expected, a graduate should acquire knowledge and skills in development, then collaborations with development studies departments are a necessity. The fact that East Anglia and Reading Universities are, perhaps, well-known (among Western universities) for these programmes within development studies-related departments says a lot about how development studies as a field views communication for development.

\begin{tabular}{|c|c|c|c|}
\hline University & $\begin{array}{l}\text { Degree } \\
\text { Programmes }\end{array}$ & Courses Offered & Schools / Departments \\
\hline $\begin{array}{l}\text { Malmo } \\
\text { University }\end{array}$ & $\begin{array}{l}\text { MA in Com- } \\
\text { munication for } \\
\text { Development }\end{array}$ & $\begin{array}{l}\text { Communication, Culture and Media Analysis } \\
\text { Media, Globalization and Development } \\
\text { New Media, ICTs and Development } \\
\text { Communication for Development (Project) }\end{array}$ & $\begin{array}{l}\text { School of Arts and Com- } \\
\text { munication } \\
\text { http://edu.mah.se/en/ } \\
\text { Program/HACFD }\end{array}$ \\
\hline $\begin{array}{l}\text { University of } \\
\text { Reading }\end{array}$ & $\begin{array}{l}\text { MSc in Com- } \\
\text { munication for } \\
\text { Innovation and } \\
\text { Development }\end{array}$ & $\begin{array}{l}\text { Perspectives on Development, Participatory } \\
\text { Interventions in Development, Concepts and } \\
\text { Practices of Communication, Communication } \\
\text { and Innovation in Development, Principles of } \\
\text { Communication Design for Development }\end{array}$ & $\begin{array}{l}\text { School of Agriculture, } \\
\text { Policy and Development } \\
\text { http://www.reading. } \\
\text { ac.uk/web/FILES/apd/ } \\
\text { apd_pgt_CID_prog- } \\
\text { spec.pdf }\end{array}$ \\
\hline $\begin{array}{l}\text { London } \\
\text { School of } \\
\text { Economics } \\
\text { and Political } \\
\text { Science }\end{array}$ & $\begin{array}{l}\text { MSc in Media, } \\
\text { Communica- } \\
\text { tion and Devel- } \\
\text { opment }\end{array}$ & $\begin{array}{l}\text { Critical Approaches in Media, Communica- } \\
\text { tion and Development, International Media } \\
\text { and the Global South, Theories and Concepts } \\
\text { in Media and Communication, Methods of } \\
\text { Research in Media and Communications }\end{array}$ & $\begin{array}{l}\text { Media and Communica- } \\
\text { tion } \\
\text { http://www.lse.ac.uk/ } \\
\text { study/graduate/taught- } \\
\text { Programmes2016/ } \\
\text { mscmediacommunica- } \\
\text { tionanddevelopment. } \\
\text { aspx }\end{array}$ \\
\hline $\begin{array}{l}\text { Ohio Univer- } \\
\text { sity }\end{array}$ & $\begin{array}{l}\text { MA in Com- } \\
\text { munication for } \\
\text { Development }\end{array}$ & $\begin{array}{l}\text { Introduction to Theory in Communication } \\
\text { and Development, Introduction to Research } \\
\text { Methods in Communication and Develop- } \\
\text { ment, Applied Research Methods in Com- } \\
\text { munication and Development, Seminar in } \\
\text { Communication and Development }\end{array}$ & $\begin{array}{l}\text { Centre for International } \\
\text { Studies } \\
\text { https://www.ohio.edu/ } \\
\text { global/cis/commdev/ }\end{array}$ \\
\hline $\begin{array}{l}\text { University of } \\
\text { Queensland }\end{array}$ & $\begin{array}{l}\text { MA in Com- } \\
\text { munication } \\
\text { (Communica- } \\
\text { tion for Social } \\
\text { Change) }\end{array}$ & $\begin{array}{l}\text { Communication for Social Change, Commu- } \\
\text { nication and Social Movements, Participatory } \\
\text { Development Communication, Participatory } \\
\text { Media Production, Community Media and } \\
\text { ICTs in Development and Social Change, } \\
\text { Communication for Social Change Practicum }\end{array}$ & $\begin{array}{l}\text { School of Journalism and } \\
\text { Communication (Centre } \\
\text { for Communication for } \\
\text { Social Change) } \\
\text { http://www.uq.edu.au/ } \\
\text { ccsc/opportunities }\end{array}$ \\
\hline
\end{tabular}


Article: Critical reflections on the theory versus practice debate in communication ...

\begin{tabular}{|c|c|c|c|}
\hline University & $\begin{array}{l}\text { Degree } \\
\text { Programmes }\end{array}$ & Courses Offered & Schools / Departments \\
\hline $\begin{array}{l}\text { University of } \\
\text { the Philip- } \\
\text { pines }\end{array}$ & $\begin{array}{l}\text { BSC, MSc, PhD } \\
\text { MSc in Devel- } \\
\text { opment Com- } \\
\text { munication }\end{array}$ & $\begin{array}{l}\text { Development Communication, } \\
\text { Educational Communication, Science Com- } \\
\text { munication and Development Journalism }\end{array}$ & $\begin{array}{l}\text { College of Development } \\
\text { Communication }\end{array}$ \\
\hline $\begin{array}{l}\text { Pontifica } \\
\text { Universidad } \\
\text { Catolica del } \\
\text { Peru (Catho- } \\
\text { lic University } \\
\text { of Peru) }\end{array}$ & $\begin{array}{l}\text { MA in Com- } \\
\text { munication for } \\
\text { Social Change }\end{array}$ & $\begin{array}{l}\text { Writing for Media, Communication Theory, } \\
\text { Language of the Media, Photography, } \\
\text { Interpersonal Communication, Theories and } \\
\text { Politics of Development, Organisational } \\
\text { Communication, Information Technology, } \\
\text { Democracy and Development }\end{array}$ & $\begin{array}{l}\text { School of Communica- } \\
\text { tion Sciences and Arts }\end{array}$ \\
\hline $\begin{array}{l}\text { University of } \\
\text { East Anglia }\end{array}$ & $\begin{array}{l}\text { MA in Media } \\
\text { and Interna- } \\
\text { tional Develop- } \\
\text { ment }\end{array}$ & $\begin{array}{l}\text { Media and International Development, Media } \\
\text { and Development in Practice, Media and } \\
\text { Society }\end{array}$ & $\begin{array}{l}\text { School of International } \\
\text { Development } \\
\text { https://www2.uea.ac.uk/ } \\
\text { study/postgraduate/ } \\
\text { taught-degree/detail/ } \\
\text { ma-media-and-interna- } \\
\text { tional-development }\end{array}$ \\
\hline $\begin{array}{l}\text { Johns } \\
\text { Hopkins } \\
\text { University }\end{array}$ & $\begin{array}{l}\text { Master of } \\
\text { Public Health }\end{array}$ & $\begin{array}{l}\text { Social and Behavioural Sciences, Public Health } \\
\text { Biology, Public Health Practice, Population } \\
\text { Dynamics, Policy and Problem Solving, Man- } \\
\text { agement Sciences, Epidemiology, Environmen- } \\
\text { tal Health, Biostatistics, Academic Research } \\
\text { and Ethics }\end{array}$ & $\begin{array}{l}\text { Bloomberg School of } \\
\text { Public Health } \\
\text { http://www.jhsph. } \\
\text { edu/academics/ } \\
\text { degree-programs/ } \\
\text { master-of-public-health/ } \\
\text { program-overview/full- } \\
\text { time.html }\end{array}$ \\
\hline
\end{tabular}

An ideal situation would be one in which schools/departments of development (international/rural development) and media and communication (journalism, arts, humanities) co-offer these graduate programmes. This is to avoid the absence of certain critical elements such as program planning or monitoring and evaluation -- crucial components that are taught in most development studies programmes.

\section{A Communication for Development Specialist}

The emergence of the C4D training at the UPLB and its institutionalisation within the UN system was, indeed, an acknowledgement that development practice on the ground was calling for what Gumucio Dagron and Rodriguez (2006) describe as "a new type of communicator." This communicator was not a journalist but rather "a communication professional with all the necessary know-how, competences, and commitment to work hand-in-hand with those engaged in development and social change processes" (Gumucio Dagron \& 
Rodriguez, 2006, p. 10). Likewise, Louis Peirano (2006), who contributed to the establishment of the MA Programme in Communication for Social Change at the Catholic University of Peru, describes a C4D specialist as someone equipped with the communication concepts and techniques to promote active participation among citizens in their society's development processes. This person is

\begin{abstract}
an expert in diagnosing communication problems, planning solutions and monitoring and evaluating results. [Has] interdisciplinary work capabilities, comprehensive vision of development and methodological know-how. [Is] sensitive to local, national and global issues and must have the ability to put themselves in someone else's place, work as a team and lead, mediate and reconcile interests, in addition to having initiative and creativity. [Has] fundamental skills as driver of communication processes for social change. [...] Must seek to promote democratic practices both in organisations and in the relationships between the various development actors (Peirano, 2006, Mazi Online).
\end{abstract}

Today, numerous organisations continue to explore and experiment with communication for development in various ways. Within the three C4D approaches introduced in Media, Communication and Development (2012) are various professional portfolios that require different skill sets, knowledge and expertise. Since journalism programmes did not have the capacity to produce this specific graduate, and because there were no sufficient training programmes in communication for development to produce these graduates in the 1970s/1980s, development organisations chose the easy option. They would recruit graduates in agriculture communication and extension, journalism and communication. Then, they provided them with short-term, on-the-job training. Over time, with increasing numbers of journalism graduates being recruited for these jobs, there was a misconception that journalism or public relations students could also double as development communicators. As Gumucio Dagron and Rodriguez (2006, p. 10) observe, "communication positions within development and social change projects are filled with people doing posters, newsletters, radio and video programmes, and public relations." There is, thus, a focus on media production skills without understanding the development context within which these skills and the resultant media content will be produced. It is clear, therefore, that a training programme in CFSC or C4D is epistemologically different from mainstream journalism, public relations and communication -- not just in content but also in methodology and approach. Gumucio Dagron and Rodriguez (2006, p. 11) suggest four key attributes that govern the communicator's strategic ability to harness communication as a pathway to achieve social change, observing:

What actually makes the 'new communicator or social change' is this mixture of experience in the field, a special sensibility and empathy to work with communities, and knowledge of communication theories, methodologies, tools, and technologies. [...] In communication for social change the process is more important than the products. 
Likewise, Quebral $(2008,2011)$ sees this communicator as a facilitator who moderates dialogues among stakeholders in these processes. The observations by Gumucio Dagron and Rodriguez (2006) as well as those of Quebral $(2008,2011)$ resonate with the way most international and local development organisations understand and define the role of a communication for development specialist. Such organisations have a specific minimum package of technical knowledge and skills that a specialist must have if they are to be offered a job.

It is very clear that the package of knowledge and skills demands more from a C4D specialist than has been spelled out by Gumucio Dagron and Rodriguez (2006) as well as Waisbord (2005). In terms of training, this specialist can come from a range of fields beyond media, communication or development studies. The emphasis on social and behavioural sciences, motivational psychology, planning for behaviour development and psychology demonstrates that behavioural research skills are becoming a must in this field. As such, C4D training has to be open to contributions from social psychology, development management, and also public health. In terms of the qualifications and knowledge, media and communication programmes should collaborate with other Disciples to ensure graduates are well rounded in the sciences of human behaviour. The Masters in Public Health at Johns Hopkins University and, perhaps, other similar programmes seem to have what the media and communication programmes need. The UN job description below shows the necessary requirements for a generic C4D specialist, which gives us an idea of what kind of graduates training institutions should actually focus on producing.

UN Communication for Development Specialist

Skills (Duties and responsibilities)

- Designs, manages, and facilitates the implementation of programme communication strategy, plan of action and activities for strategic communication and promotion for social and behavioural change in support of country programme delivery;

- Organizes the research, development, pre-testing, and production of culturally relevant communication materials;

- Develops and enhances strong partnerships with community groups, leaders and other partners in the community and civil society for promotion of participation in social and behavioural changes supportive of programme goals;

- Develops training materials and activities to build capacity for participatory and behaviour change communication;

- Provides effective coordination and technical support to government counterparts and other partners in the development and strategic use of communication for social development.

- Monitor and evaluate programme activities and pre-evaluation reports. Exchange findings, experiences, lessons learned and new methods with partners.

- Participate in the budget planning and ensure the compliance and the optimal appropriation of allocated programme funds. 


\section{Technical Knowledge:}

- Education: Advanced university degree in the social/behavioural sciences, (Sociology, Anthropology, Psychology, Health Education) with emphasis on strategic communication planning for behaviour development, social mobilization, participatory communication, and research.

- Knowledge of current developments in the fields of: communication theory, motivational psychology, adult learning theory, indigenous media, community organization and participation, strategic communication planning, behaviour analysis, formative research and evaluation of communication interventions;

- Knowledge of inter-disciplinary approach in programme development and implementation in programme communication, social mobilization and behavioural change;

- Knowledge of and experience in emergency operations and management;

- Knowledge of and skills in programme communication networking, advocacy and negotiation;

- Knowledge of training/facilitation and impact evaluation of communication intervention;

- Knowledge and experience to organize and implement training, including development of curricula and methodologies. Knowledge of community capacity building;

- Knowledge and experience in the methods of communication to clearly and concisely express ideas and concepts in written and oral form and to listen to and acknowledges others' perspectives and views;

- Computer knowledge, skills and practical experience, including internet navigation, network, telecommunications and various office applications.

Table 1: Communication for Development Specialist Job Description. Source: UNICEF, 2016.

The job description above has three skills and tools that stand out: (a) organizing the research, development, pre-testing, and production of culturally relevant communication materials; (b) developing and enhancing strong partnerships with community groups, leaders and other partners in the community and civil society for promotion of participation in social and behavioural changes supportive of programme goals; and (c) developing training materials and activities to build capacity for participatory and behaviour change communication. These skills require training to be oriented to ensure that students are offered the opportunity to work with communities and understand the science of influencing behaviour and how to measure the link between C4D interventions, on one hand, and their impact, on the other. It should be remembered that graduate programmes are intended to produce a development specialist (or, in some cases, a public health specialist) who has relevant communication skills. Therefore, it is not an overstatement to argue that what we are interested in having a graduate who understands the process of development and how communication can facilitate the involvement of people (Quebral, 1988; Ramiro Beltran, 1993/2004; Peirano, 2006). In this case, then, it is vitally significant to have a level of development theory in the curriculum. The proposal below spells out the minimum package of a skill set that graduate programmes in C4D should offer. 
Article: Critical reflections on the theory versus practice debate in communication ...

\section{Minimum Package of Knowledge and Skills for a C4D Specialist}

From the generic UN advert, it is very clear that there are two forms of attributes. The first concerns knowledge about the field, and the second encompasses the actual skills that this expert should have. This has implications for C4D training and curriculum development.

\section{Part A: Knowledge and Expertise}

This aspect should cover courses that allow for a general understanding of development issues and how communication figures in that. Critical also is the centrality of power (Waisbord, 2005). What would the generic template of courses comprise?

\section{1: Critical Perspectives in Development Theory and Practice}

Even though the concept of social change has become a defining attribute of training programmes, most development organisations nowadays use C4D; and, if they are looking to recruit, they will be looking for a C4D specialist or officer. So, in terms of training programmes, there is a need to cultivate in students a critical understanding of development, not as a known phenomenon but, rather, as a contested terrain of theories, principles, practices and space. The neo-imperialist discourse of and within development seems to have emerged from Western domestic and foreign policies in which the Global South was ideologically flattened and described as homogenous. It was, then, stripped of its diversity, and its elements were linked together through their underdevelopment and backwardness, which could only be eradicated by projecting a model of Anglo-American society.

A student will be taken through these historical perspectives, the postcolonial perspectives of the Latin American dependistas, other critical perspectives from other parts of the South, postmodernist notions of development and multiplicity, including questions of community, and asset-based notions of development. At the centre of these critical perspectives should be an analysis of power. An institution might wish to add critical theory to this and bring in questions of gender, feminism or even theories of representation. If a communicator has to communicate development, they at least deserve to know what this phenomenon is and where it comes from. This sort of curriculum is already offered at many universities but not necessarily in media and communication departments; the challenge is for media and communication scholars and departments to cultivate relationships that override the pride and intellectual territorialism that seems to bedevil many institutions. If the emphasis is on public health communication, collaborating with a school of public health to offer courses related to behavioural sciences would be commendable.

\section{2: Understanding C4D or CfSC Holistically}

It is important that graduates understand what this field is all about. This implies that students be exposed to the various schools of thought that have characterised scholarship and practice. Gumucio Dagron and Rodriguez (2006) emphasise that there is a need for a comprehensive and holistic "understanding of communication as a process in development and social change" that should be promoted and emphasised among development 
policymakers. Importantly, years of research and teaching the field have demonstrated that there are three dominant approaches that have characterised the field. While a development communicator is equipped with critical perspectives on development, they will also understand that each of the three approaches has its own intellectual and historical life, which, in practice, requires a somewhat distinct set of professional attributes and capabilities. What this means is that, if a C4D specialist is employed in any of the professional fields within the three $\mathrm{C} 4 \mathrm{D}$ approaches, they will be able to adapt their skill set and knowledge. As discussed, these three approaches are media for development (producing content), media development (building media systems and capacities) and participatory communication (establishing deliberative processes).

\section{Courses on Power and/or Media Power}

Waisbord's (2005) emphasis on power requires that critical attention be paid to a course that offers students an opportunity to examine various theoretical perspectives on power. The LSE's Media and Communication Department used to offer a compulsory course called 'Key Theories and Concepts in Media and Communication', which provided an intellectual space for interrogating power and its processes, considering that everything is mediated (Livingstone, 2009). Substitute courses could be found in sociology, political science or other departments.

\section{Part B: Skill Set or Package}

Referring to a specialist's set of required skills, Waisbord $(2005, \mathrm{p}$. 80) discusses the recognition of the "need for a multiplicity of communication strategies to improve the quality of life in communities." What are these skills and strategies?

\section{4: Communication for Development Research}

There are three key areas that are critical for research: 1) evidence integration, 2) monitoring and evaluation, and 3) situation analysis. With regards to the increased integration of 'investment thinking' (UK Government, 2013; UNAIDS, 2012) in development thinking and practice, there is a need to strengthen graduate offerings to reflect needs on the ground. Considering that the GOALS and SPECTRUM models are very mathematical and statistical in orientation, graduate students should have a basic understanding of how these models work and how they inform programming. The monitoring and evaluation aspect requires graduates to have the skills to develop and understand programme/project indicators, logical frameworks, and data collection and analysis. Again, for most media and communication programmes, the basic research skills are offered but without an emphasis on quantitative approaches. Whilst quantitative research and its approaches are gaining prominence in C4D practice, they seem to be footnoted by numerous training C4D programmes. Exceptions of course are the few Masters programmes such as the John Hopkins Masters in Public Health with strong quantitative research components. In terms of the 
C4D situation analysis, it is increasingly becoming the basis for participatory action research that enables experts and communities to contribute to programme design and planning by ensuring that local voices are heard and integrated into policies (UNICEF, 2009).

\section{5: Engaging with Stakeholders and Communities}

A major aspect of C4D training programmes is to produce graduates with the tools and skills to engage with stakeholders and communities. This implies communicators who demonstrate three attributes. First, they demonstrate leadership in working with teams and others (Dagron Gumucio \& Rodriguez, 2006). Engagement here does not just refer to mere facilitation of group discussions but, rather, a conscious awareness of how the flow and contestation of power is going to enable or not enable the articulation of certain voices and the deliberate efforts one puts in place to ensure that marginalised voices are provided with the knowledge and tools to contribute to the deliberative processes.

A second attribute in terms of stakeholder and community engagement is the ability to tell stories -- especially, other people's stories. In media for development, for example, a development communicator will visit social groups in order to hear their perspectives on a social or development problem. Out of these stories and episodes, one must construct a narrative that is very interesting, captivating and educational so that, when people listen to it, they will be moved to begin to question their own socio-economic reality. In order to tell such stories, one must be creative but, at the same time, very empathetic and understanding to those marginalised and oppressed. This is the case with entertainment-education or social and behaviour change communications.

A third attribute is listening, the ability to be tolerant of differing perspectives to sympathize with why others differ with the rest, and ultimately, to integrate such contrasting perspectives in the final narrative. There are many methodologies for listening. Participatory rural communication appraisal is a great example of developing a communication strategy with and alongside people on the ground. Participatory mapping is another tool that allows collaborative analysis of development challenges in which experts and subjectmatter specialists are made to witness how people view their own problems. Perhaps alluding to this skill set, Quebral (1988) advises development communicators to start with specific issues arising from the general problems of a society, to learn as much as they can about the stakeholders involved, and then to co-fashion with the various stakeholders a course of action to be followed.

\section{Leadership Skills}

One extant challenge facing the C4D field today is the lack of leadership. My experience with development organisations, including the $U N$ itself, is that there are all these experts who may have a great understanding of how C4D operates but have no leadership skills. They spend time undermining the work of others, peddling gossip, refusing to listen to alternative viewpoints and, basically, failing to network and work with partners. For C4D 
training programmes, there is a need to produce development communicators with leadership qualities, enabling them to participate actively and contribute to the formulation of development interventions that place emphasis on community engagement strategies right from the start.

\section{Conclusion and Afterthoughts}

There is a proliferation of communication for development training programmes being established by universities and colleges the world over. This is very commendable, especially considering that graduates in this field are in high demand. Each week, numerous organisations advertise thousands of jobs on websites such as Communication Initiative, ReliefWeb, Devex, DevNet and others. UN agencies such as UNICEF, UNDP or UNESCO are in constant need of communication for development specialists to contribute to programme planning and implementation. What this means is that there is need to understand clearly what kind of graduate is required out there. At the same time, universities want to produce a graduate who is going to be reflexive and critical of what they are doing, a critically and socially conscious and responsible communication for development specialist. This is not necessarily a graduate of mass communication, general communication, or journalism programme (Gumucio Dagron \& Rodriguez, 2006).

We are talking about a communication for development graduate who has acquired the necessary specialist knowledge in development thinking (from public health to agriculture, depending on their specialisation) as well as in communication for development. This is a graduate with a minimum package of skills that encompasses C4D situation analysis as well as stakeholder and community engagement. This is a graduate who is empathetic to the plight of people, who is humble and understanding. Much of the Global South today is littered with 'experts' who are culturally condescending, sexist, misogynistic, and racist, who believe that because they come from certain corners of the globe, they are always right. These are not the specialists the field of C4D needs. University training in C4D, therefore, is not just about exposing students to certain theories and skill sets but, rather, building up a personality, a consciousness and character of an empathetic, understanding, tolerant and critical practitioner who is going to help people and policymakers to think beyond their horizons in the quest to create a more equal, just and democratic society. Otherwise, there will continue to be, as is currently often the case, a great disjuncture between what academic programmes in communication for development are offering and what development organisations are demanding on the ground.

Finally, this paper pays attention to a debate that is raging in the field: Communication for social change or communication for development? Both concepts are problematic in many ways. Development is slippery, contested, rudderless, dangerous, and very fluid. Development for policymakers may not necessarily be the same for subaltern and marginalised groups. Likewise, social change is slippery, fluid and in a permanent state of 
uncertainty. It is largely shaped by the prevailing socio-political situation. Yet, it can be pointed out that, in the social science debates on the hierarchy of results, we start with outputs, move to outcomes, and finally go to impact. Often, social change is at the level of impact, and this is problematic. Small victories at the level of outputs and outcomes are essential because, cumulatively and over a long period of time, they bring us desired results. As such, C4D seems to make more sense when we are discussing the effectiveness of our interventions at the lowest levels of outputs and, perhaps, outcomes; and, in very few cases, we talk about social change because of so many factors including external funding, lack of sustainability or the nature of program- or project-based interventions. The focus should be on producing graduates with leadership skills and qualities, who understand power, how it flows and is contested in and within social groups; those who have a comprehensive understanding of the subject matter about which they want to communicate. It is, thus, recommended that the networks of C4D training be strengthened or created to provide critical platforms for sharing curricula content, training philosophies and methodologies, so that there is consonance between theory and practice. The role of and the need for the Communication for Social Change Consortium is more critical now than ever before; otherwise, the cliché that theory is practice could not be farther from the truth when it comes to communication for development.

\section{References}

Figueroa, M.E, Kincaid, D.L, Rani, M., \& Lewis, G. (2002). Communication for Social Change: An Integrated Model for Measuring the Process and Its Outcomes. New York: Rockefeller Foundation. Retrieved October 30, 2016, from: http://www.communicationforsocialchange.org/pdf/socialchange.pdf

Gumucio Dagron, A., \& Tufte, T. (2006). Communication for Social Change Anthology: Historical and Contemporary Readings. South Orange, NJ: Communication for Social Change Consortium.

Gumucio Dagron, A., \& Rodriguez, C. (2006). Time to call things by their name: The field of communication and social change. Media Development, LIII (3), 9-16.

Gwin Wilkins, K., Tufte, T., \& Obregon, R. (Eds.) (2014). The Handbook of Development Communication and Social Change. Hoboken, NJ: Wiley-Blackwell.

Hemer, O., \& Tufte, T. (2005). Media and Glocal Change: Rethinking Communication for Development. Buenos Aires: CLACSO

Livingstone, S. (2009). On the mediation of everything. ICA Presidential address. Journal of Communication, 59(1), 1-18.

Manyozo, L. (2012). Media, Communication and Development: Three Approaches. London and New Delhi: Sage.

Manyozo, L. (2007). University training in communication for development: Trends and approaches. Media Asia: An Asian Mass Communication Quarterly, 34 (1), 51-60.

Obregon, R., \& Waisbord, S. (Eds.) (2012). The Handbook of Global Health Communication, Development and Social Change. Hoboken, NJ: Wiley-Blackwell. 
Peirano, L. (2006). Developing a unique proposal for communication for development in Latin America. Mazi Online. Retrieved October 30, 2016, from: http://www.communicationforsocialchange.org/maziarticles.php?id=298

Quebral, N. (2011). Development communication, Los Baños style. Public Lecture, London School of Economics and Political Science during an Award of an Honorary Doctorate in Media and Communication, December 20. Retrieved October 30, 2016, from: http://www.lse.ac.uk/media@lse/events/pdf/Professor\%20Nora\%20Cruz\%20Quebral\%20Dec\%202011\%20lecture.pdf

Quebral, N. (1988). Development Communication. Laguna: University of the Philippines, Los Baños.

Ramiro Beltran, L. (1993/2004). Communication for development in Latin America: A forty year appraisal. Retrieved October 30, 2016, from: http://www.southbound.com.my/communication/cul-ch.htm

Rockefeller Foundation. (1997). Bellagio Conference Report - Communications and Social Change: Forging Strategies for the $21^{\text {st }}$ Century. Retrieved from: http://web.asc.upenn.edu/gerbner/archive.aspx?section $\mathrm{ID}=114$ \&packageID $=560$

UK Government. (2013). DFID Malawi HIV prevention programme: Business case. Lilongwe and London: DFID and UK AID. Unpublished policy document.

UNAIDS. (2012). Investing for Results. Results for People: A People-Centred Investment Tool towards ending AIDS. Geneva: Joint UN Programme for HIV and AIDS. Retrieved from: http://www.unaids.org/sites/ default/files/sub_landing/files/JC2359_investing-for-results_en.pdf

UNICEF. (2009). UNICEF guidelines for undertaking a communication for development situation analysis. New York: UNICEF, Unpublished Guidelines.

UNICEF. (2016). Communication for development specialist, UNICEF, Job advert. Retrieved October 30, 2016, from: https://jobs.undp.org/cj_view_job.cfm?cur_job_id=63013

Waisbord, S. (2005). Five key ideas: coincidences and challenges in development communication. In O. Hemer, \& T. Tufte (Eds.), Media and Glocal Change: Rethinking Communication for Development (pp.7790). Buenos Aires: CLACSO.

Linje Manyozo, PhD

Senior Lecturer, Communication for Development, School of Media and Communication, RMIT University, Melbourne

Linje.manyozo@RMIT.edu.au 